\title{
遺伝的アルゴリズムの空間構造形態解析への応用 AN APPLICATION OF GENETIC ALGORITHMS TO FORM FINDING ANALYSIS OF SPATIAL STRUCTURES
}

\author{
三井和男*, 登坂宣好** \\ Kazuo MITSUI and Nobuyoshi TOSAKA
}

\begin{abstract}
Applicability of genetic algorithms (GAs) to the form optimization problem of structures is discussed in this paper. The form optimization problems on truss structures under the prescribed displacement mode are solved by using GAs. These problems have strong nonlinearity, and the layout of the members is deeply concerned with the existence condition of solutions. In the present study, the form finding method in which not only the positions of the objective nodes but also the layout of the members are encoded to strings in the GAs as the design parameters of the structure is proposed, and the effectiveness of the method is examined. Moreover, the form finding method is extended to the minimal surface problem, in which several control points of a spline function are introduced in order to describe the shape of the membrane surface.
\end{abstract}

Keywords: Genetic algorithms, Form finding, Truss, Membrane, Minimal surface, Optimization 遺伝的アルゴリズム, 形態解析, トラス, 膜, 極小曲面, 最適化

1. 序

構造システムは、トラスやフレーム等の離散型と 梁、板、膜、シェル等の連続型に分類することができ るい。ここで取り扱う問題は、離散型の構造システム であるトラス構造物のホモロガス変形を指定した構造 設計問題と、連続型の構造システムである膜構造の原 形曲面の形状決定問題である。

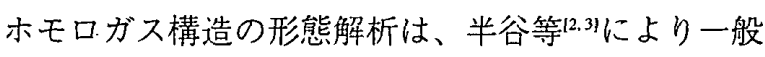
逆行列を用いた研究が進められている。この問題にお ける形態解析は主に位相決定問題と位置決定問題から 構成される。位相の決定は目標とする解の存在条件と 深い関連があり、また位置の決定の前提となるため非 常に重要な問題である。また、位置の決定に対し問題 が強い非線形性を有しているため Newton-Raphson 法 等が用いら机る場合が多いが、初期値への依存性が非 常に強い場合や、設計パラメータの增加に伴って解空 間の多峰性が顕著な場合があり、解析を困難なものに している。

*日本大学生産工学部数理工学科 助教授 $\cdot$ 工博

** 日本大学生産工学部数理工学科 教授. 工博
本論では、この困難を解決するため位相に関する情 報と位置に関する情報の両方を遺伝子としてコーディ ングし、多峰性のある問題や最適配置問題に有効であ るとされる遺伝的アルゴリズム[4] (Genetic Algorithms :GA）を導入して、位相と位置さらに部材断面の決定 を同時に行なう解析法を提案し、その有効性を検討す る。このような非線形問題では一般に複数の解が存在 し、それらの解の中から一つを選択するためには何ら かの条件を追加しなければならない。本論ではさら に、多目的 $\mathrm{GA}^{[\mathrm{[j}}$ の手法を導入することによってこのよ うな問題に対する $\mathrm{GA}$ の掂張性を検討する。

一方、連続型の構造システムの問題で興味深いのは シェルや膜の形状決定問題である。 Ramm ${ }^{[6]}$ は応力レ ベル関数と歪エネルギー関数を目的関数として採用し たシェルの形状最適化を提案し、幾つかの例題で数値 計算を行って最適形状を示している。また、大森等[7] は系の重力ポテンシャルエネルギーを極小化すること により吊り下げ曲面の形状を求めている。このように

Assoc. Prof., Dept. of Mathematical Engineering, College of Industrial Technology, Nihon Univ., Dr. Eng.

Prof., Dept. of Mathematical Engineering, College of Industrial Technology, Nihon Univ., Dr. Eng. 
シェルや膜の形状決定問題はそれらの形状に対応する 何らかの汎関数を最小化する問題として定式化でき る。本論ではこれらの問題への遺伝的アルゴリズムの 適用の可能性を示すために極小曲面問題を取り上げ る。極小曲面は膜構造の原形曲面として採用される等 張力曲面と幾何学的に同一である。この問題も非線形 性が強くさまざまな数值解析手法 $\left.{ }^{8,9}, 10\right]$ が提案されてい る。また、対話型可視化システム[11,12]の導入によって 形態生成を支援する試みもなされている。幾つかの制 御点とスプライン関数によって膜面を表現し、この制 御点の位置を遺伝子にコーディングすることによって 面積が極小となる膜面形状を決定する問題に GA を適 用する。

\section{2. 遗伝的アルゴリズム}

GAは、生物進化のメカニズムと考えられる選択淘 汰と突然变異の原理に着想を得たアルゴリズムであ

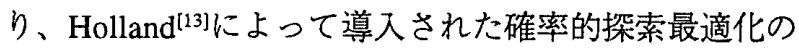
一手法である。GAでは、Fig.1に示すようにまずはじ めに初期化を行う。これは一様乱数を発生させること によりランダムに初期集団を発生させる操作である。 このとき、集団を構成する各個体は設計パラメータを 2 進数で記述した遺伝子 (string)によって表現される。 このような集団は、通常一定の個体数 (population) で 構成され、世代 (generation) と呼ばれる。次に各世代 に执いて繁殖 (reproduction)、交叉 (crossover)、突然 変異 (mutation) という過程をある一定の終了条件を満 たすまで繰り返す。

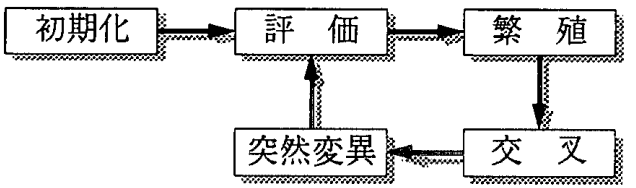

Fig.1 単純 GA

交叉は、二つの個体の遺伝子を組み換えることによ り次世代の遺伝子を作る操作であり、単なるランダム 探索とは異なるGAにおいて最も特徴的な過程であ る。子となる遺伝子に両親の遺伝子の優れた部分を組 み合わせることができれば解の探索に扔ける飛躍をも たらすからである。ここで集団の中の全ての個体が交 叉するのではなく、特定の割合で交叉が行われる。こ の割合は交叉率と呼ばれる。

突然变異は遺伝子を一定の確率で変化させる操作で ある。突然変異はある世代における集団全体が局所解 に陥ってしまったとき、この局所解から抜け出す可能 性が期待できる。突然変異が発生する確率は突然変異 率と呼ばれ、極く低い確率が与えられるのが普通であ る。
繁殖では淘汰 (selection) が行なわれ、適応度の高い 遺伝子はその適応度に比例して次世代に自分と同じ遺 伝子を残す確率が高くなり、逆に適応度の低い遺伝子 は死滅する確率が高くなる。これによって解が収束す る性質を持つ。各個体の適応度は、それぞれの個体の 遺伝子をいくつかの設計パラメータに解読してから、 これらの評価関数值を計算し、この評価関数值から適 応度を計算する。

\section{3. ホモロガス構造の形態解析}

Fig. 2 に示すトラス構造を考える。部材の断面積お よび弾性定数は一定であるとする。また、水平抢よび 垂直部材は存在が決定しているものとし、斜材は形態 解析によってその配置が決定される部材であってその 存在は未定である。上弦節点 $1,2,3$ に均一な鉛直方向 荷重が作用するとき、ホモロガス変形は節点 $1,2,3$ の 鉛直方向変位が同一となることを意味するが、適当に 選んだ形態は一般にこれを満足しない。ここでは前述 の 4 本の斜材の配置と節点 4 の 鉛直 座標值 $\mathrm{y}_{4}$ を設計 パラメータとして選択し、ホモロガス変形を满足する 形態を解析する。

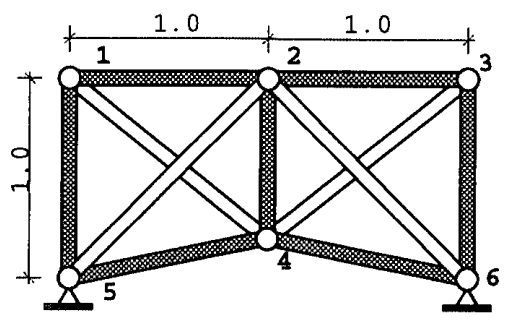

Fig. 2 解析モデル

この問題は強い非線形性を有する問題であり、その ため何らかの形で Newton-Raphson 法のような非線形 方程式の数值解析手法が用いられる場合が多い。しか し、これらの方法は初期值への依存性が非常に強い場 合があり、期待した形態が得られない場合がある。こ の問題では、例えば後に示す目的関数 $\mathrm{f}$ を設計パラ メータ $\mathrm{y}_{4}$ の関数であると考えて所謂感度 $\partial \mathrm{f} / \partial \mathrm{y}_{4}$ を計算 しなければならない。これは Fig. 3 に示すように設計 パラメータ y 4 の増加掠よび減少にともなって0に漸近 する傾向があり、初期值によっては解が求められない 場合や、収束計算の過程で感度 0 の領域に陥り解析で きない場合がある。感度 $\partial \mathrm{f} / \partial \mathrm{y}_{4}$ を求める必要のない GA の有効性が期待される点である。

Figs. 4, 5 はそれぞれ Fig. 6 に示すA およびDの部 材配置に対する設計パラメータ $\mathrm{y}_{4}$ と節点 1,2 の鉛直方 向変位の関係を示したものである。Fig. 4 では二つの 曲線の交差する $\mathrm{a}$ と b の位置にホモロガス変形を満足 する解が存在する。しかし、Fig. 5 ではホモロガス変 形を満足する解は存在せず、部材の配置、すなわち位 

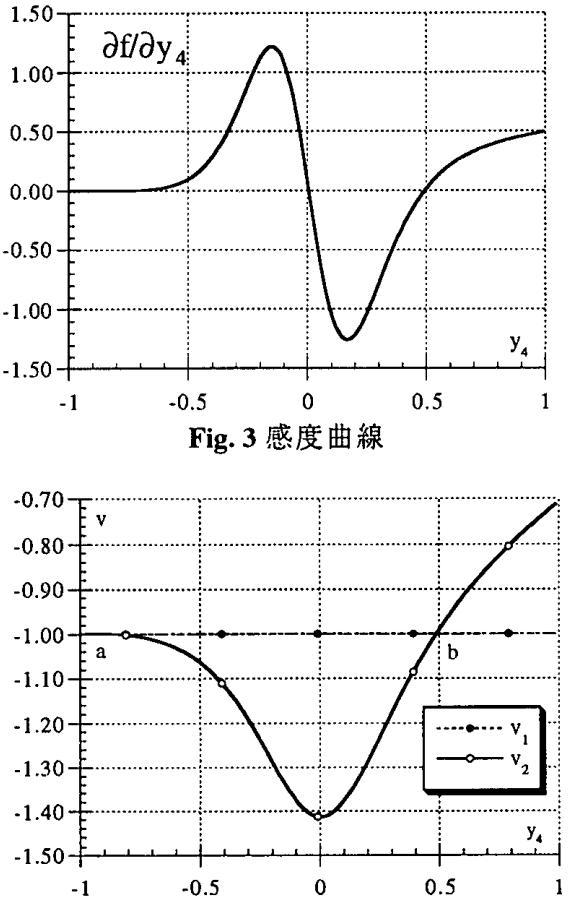

Fig. 4 部材配置 $\mathrm{A}$ の解

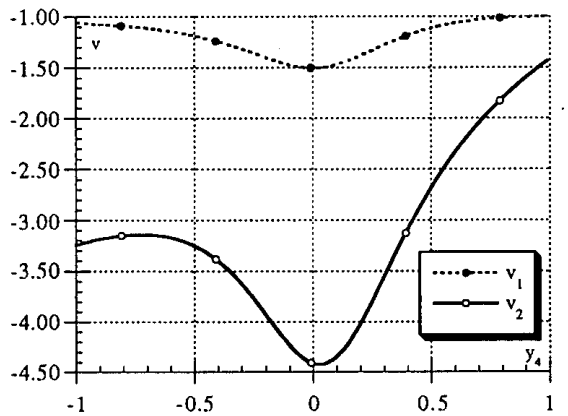

Fig. 5 部材配置 Dの解

相の決定が目標とする解の存在条件と深く関係するこ とがわかる。このような問題は通常の数值解析手法で は取り扱いが難しく、この点も GA の有効性が期待さ れる点である。

\section{1 目的関数と適応度}

トラスの各節点についての変位を計算し、節点 1,2 , 3における鉛直方向変位をそれぞれ $\mathrm{v}_{1}, \mathrm{v}_{2}, \mathrm{v}_{3}$ とすれば、 目的関数は式（1）で表すことができる。

$$
\mathrm{f}=\left(\mathrm{v}_{1}-\mathrm{v}_{2}\right)^{2}+\left(\mathrm{v}_{2}-\mathrm{v}_{3}\right)^{2}+\left(\mathrm{v}_{3}-\mathrm{v}_{1}\right)^{2}
$$

この $\mathrm{f} 0$ または最小にする構造形態を表現する遺伝 子を探索する。適応度 (fitness) は次式により計算し た。

$$
\text { fitness }=1 /(1+f)
$$

3.2 設計パラメータのコード化

(1) 節点の位置のコード化
節点4の鉛直座標を $\mathrm{y}_{4}$ とし、 $\mathrm{y}_{4}$ が区間 $\left[\mathrm{L}_{\mathrm{a}}, \mathrm{L}_{\mathrm{b}}\right]$ の中 にあるものとする。位置のコード化のために $\mathrm{y}_{4}$ のとり うる值を 0 から 255 とする 8 ビットの 2 進数で表現 し、これを位置を示す遺伝子とする。したがって遺伝 子と $\mathrm{y}_{4}$ の間には次の関係式が成立する。ここで、 $\mathrm{N}$ は 遺伝子の意味する 0 から 255 の 10 進数である。

$$
\mathrm{y}_{4}=\mathrm{L}_{\mathrm{a}}+\mathrm{N}\left(\mathrm{L}_{\mathrm{b}}-\mathrm{L}_{\mathrm{a}}\right) / 255
$$
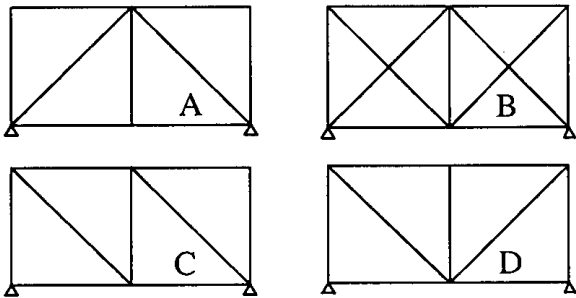

Fig. 6 部材配置

(2) 位相のコード化

トラスの部材配置を遺伝子にコード化する。ここで は簡単にするために Fig. 6 に示すような 4 種類のパ ターンをあらかじめ決めておき 2 ビットの 2 進数で表 現する。A の部材配置を 2 進コード 00、B の部材配 置は 2 進コード01とコード化し同様に C、D の部材配 置をそれぞれ 10、11 とコード化する。

(3) 位置と位相のコード化

位置の情報を持つ 8 ビットの遺伝子と位相の情報を 持つ 2 ビットの遺伝子をつなぎ合わせて Fig. 7 の様な 10 ビットの遺伝子とした。

$$
\begin{aligned}
& \begin{array}{|l|l|l|l|l|l|l|l|}
\hline 1 & 1 & 0 & 1 & 0 & 0 & 1 & 0 \\
\hline
\end{array} \oplus \begin{array}{|l|l|l|}
\hline & 0 \\
\hline
\end{array} \\
& =\begin{array}{l|l|l|l|l|l|l|l|l|l|}
\hline 1 & 1 & 0 & 1 & 0 & 0 & 1 & 0 & 1 & 0 \\
\hline
\end{array}
\end{aligned}
$$

Fig. 7 位置と位相の遺伝子へのコード化

\section{3 ホモロガス構造の解析結果}

Fig. 2 のトラス構造モデルについて $\mathrm{L}_{\mathrm{a}}=-1.0 、 \mathrm{~L}_{\mathrm{b}}=$ 1.0 として解析を行なった結果、Fig. 8 に示す部材数 9 のホモロガス構造 (1) とFig. 9 に示す部材数 9 のホ モロガス構造 (2) さらにFig. 10 に示す部材数 11 のホ

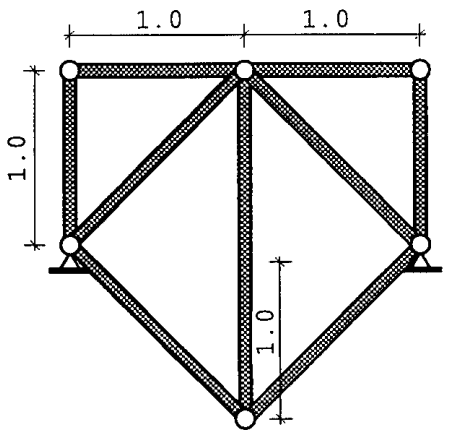

Fig. 8 ホモロガス構造（1） 


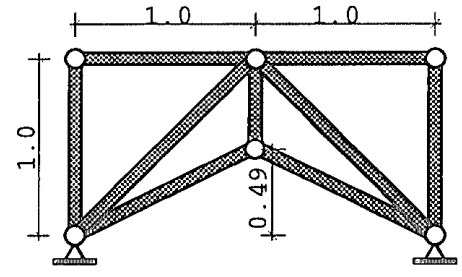

Fig.9ホモロガス構造（2）

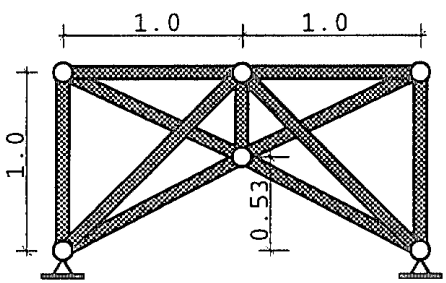

Fig. 10 ホモロガス構造（3）

モロガス構造 (3) の三つの形態が得られた。何れの解 に収束するかは、ランダムに選択された初期集団に依 存する。しかし、何れかの解に収束するような制約条 件、例之ば部材数の制限などを考慮すれば解の選択は 可能である。尚、個体数は 20 、交叉率は 0.4 、突然変 異率 0.005 とした。また、20回の試行中、各々の形態 が得ら机た回数は、Fig. 8 が 8 回、Fig. 9 が 7 回、Fig. 10が 5 回である。著者等は、GAのパフォーマンスに 大きな影響をあたえると言われる突然変異率や交叉 率、個体数等のパラメータの設定に留意し、個体数 10～100、交叉率0.4 0.8、突然変異率0.002 0.05の範 囲で試行を繰り返したが、この問題ではこれらのパラ メータによるパフォーマンスへの大きな影響は認めら れず、本論では上に示した值を基準として採用した。

\section{4 ロバスト性を考慮したトラス構造}

このようにして得られた構造形態は設計条件として 一定のヤング率や既知の外荷重を与えて得られた最適 形状である。設計条件のうち例之ば外荷重が変動した 場合、その応答が解析時に期待した応答と著しく異な ることは望ましいことではない。これらの変動に対し てあまり影響を受けない性質すなわち所謂ロバス卜性 の検討は最適化に扔いて重要な問題であり、前述のよ うなホモロガス条件を満足する複数の解から一つを選 び出す一つの基準を与える。本論では外荷重の変動と その応答の変動を統計量として扱うことによりロバス 卜性を考慮した解析を行い、このような問題に対する 遗伝的アルゴリズムの拡張性を考える。

節点 $1,2,3$ に作用する鉛直荷重が不確定であると考 えてこれを確率変数 $\alpha_{1}, \alpha_{2} ， \alpha_{3}$ で表現する。これによ り生ずる変位も不確定となる。 $v_{i}^{0}(i=1,2,3)$ を既知 の荷重によって節点 $\mathrm{i}$ に生じる鉛直方向变位成分、 $v_{k}^{\mathrm{j}}(\mathrm{j}, \mathrm{k}=1,2,3)$ を節点 $\mathrm{j}$ に作用する単位荷重によっ て節点 $\mathrm{k}$ に生じる鉛直方向変位の変動成分であるとす
ると、生ずる変位は次式で表わすことができる。

$$
\left\{\begin{array}{l}
v_{1} \\
v_{2} \\
v_{3}
\end{array}\right\}=\left\{\begin{array}{l}
v_{1}^{0} \\
v_{2}^{0} \\
v_{3}^{0}
\end{array}\right\}+\left\{\begin{array}{l}
v_{1}^{1} \\
v_{2}^{1} \\
v_{3}^{1}
\end{array}\right\} \alpha_{1}+\left\{\begin{array}{l}
v_{1}^{2} \\
v_{2}^{2} \\
v_{3}^{2}
\end{array}\right\} \alpha_{2}+\left\{\begin{array}{c}
v_{1}^{3} \\
v_{2}^{3} \\
v_{3}^{3}
\end{array}\right\} \alpha_{3}
$$

したがって、目的関数 $\mathrm{f}$ は次のように書くことができ る。

$$
\begin{aligned}
\mathrm{f} & =\mathrm{c}_{0}+\mathrm{c}_{1} \alpha_{1}+\mathrm{c}_{2} \alpha_{2}+\mathrm{c}_{3} \alpha_{3}+\mathrm{c}_{4} \alpha_{1}^{2}+\mathrm{c}_{5} \alpha_{2}^{2}+\mathrm{c}_{6} \alpha_{3}^{2} \\
& +\mathrm{c}_{7} \alpha_{1} \alpha_{2}+\mathrm{c}_{8} \alpha_{1} \alpha_{3}+\mathrm{c}_{9} \alpha_{2} \alpha_{3} \\
己 & =k \\
\mathrm{c}_{0} & =\left(\mathrm{v}_{1}^{0}-\mathrm{v}_{2}^{0}\right)^{2}+\left(\mathrm{v}_{2}^{0}-\mathrm{v}_{3}^{0}\right)^{2}+\left(\mathrm{v}_{3}^{0}-\mathrm{v}_{1}^{0}\right)^{2} \\
\mathrm{c}_{1} & =2\left(\mathrm{v}_{1}^{0}-\mathrm{v}_{2}^{0}\right)\left(\mathrm{v}_{1}^{1}-\mathrm{v}_{2}^{1}\right)+2\left(\mathrm{v}_{2}^{0}-\mathrm{v}_{3}^{0}\right)\left(\mathrm{v}_{2}^{1}-\mathrm{v}_{3}^{1}\right) \\
& +2\left(\mathrm{v}_{3}^{0}-\mathrm{v}_{1}^{0}\right)\left(\mathrm{v}_{3}^{1}-\mathrm{v}_{1}^{1}\right) \\
\mathrm{c}_{2} & =2\left(\mathrm{v}_{1}^{0}-\mathrm{v}_{2}^{0}\right)\left(\mathrm{v}_{1}^{2}-\mathrm{v}_{2}^{2}\right)+2\left(\mathrm{v}_{2}^{0}-\mathrm{v}_{3}^{0}\right)\left(\mathrm{v}_{2}^{2}-\mathrm{v}_{3}^{2}\right) \\
& +2\left(\mathrm{v}_{3}^{0}-\mathrm{v}_{1}^{0}\right)\left(\mathrm{v}_{3}^{2}-\mathrm{v}_{1}^{2}\right) \\
\mathrm{c}_{3} & =2\left(\mathrm{v}_{1}^{0}-\mathrm{v}_{2}^{0}\right)\left(\mathrm{v}_{1}^{3}-\mathrm{v}_{2}^{3}\right)+2\left(\mathrm{v}_{2}^{0}-\mathrm{v}_{3}^{0}\right)\left(\mathrm{v}_{2}^{3}-\mathrm{v}_{3}^{3}\right) \\
& +2\left(\mathrm{v}_{3}^{0}-\mathrm{v}_{1}^{0}\right)\left(\mathrm{v}_{3}^{3}-\mathrm{v}_{1}^{3}\right) \\
\mathrm{c}_{4} & =\left(\mathrm{v}_{1}^{1}-\mathrm{v}_{2}^{1}\right)^{2}+\left(\mathrm{v}_{2}^{1}-\mathrm{v}_{3}^{1}\right)^{2}+\left(\mathrm{v}_{3}^{1}-\mathrm{v}_{1}^{1}\right)^{2} \\
\mathrm{c}_{5} & =\left(\mathrm{v}_{1}^{2}-\mathrm{v}_{2}^{2}\right)^{2}+\left(\mathrm{v}_{2}^{2}-\mathrm{v}_{3}^{2}\right)^{2}+\left(\mathrm{v}_{3}^{2}-\mathrm{v}_{1}^{2}\right)^{2} \\
\mathrm{c}_{6} & =\left(\mathrm{v}_{1}^{3}-\mathrm{v}_{2}^{3}\right)^{2}+\left(\mathrm{v}_{2}^{3}-\mathrm{v}_{3}^{3}\right)^{2}+\left(\mathrm{v}_{3}^{3}-\mathrm{v}_{1}^{3}\right)^{2} \\
\mathrm{c}_{7} & =2\left(\mathrm{v}_{1}^{1}-\mathrm{v}_{2}^{1}\right)\left(\mathrm{v}_{1}^{2}-\mathrm{v}_{2}^{2}\right)+2\left(\mathrm{v}_{2}^{1}-\mathrm{v}_{3}^{1}\right)\left(\mathrm{v}_{2}^{2}-\mathrm{v}_{3}^{2}\right) \\
& +2\left(\mathrm{v}_{3}^{1}-\mathrm{v}_{1}^{1}\right)\left(\mathrm{v}_{3}^{2}-\mathrm{v}_{1}^{2}\right) \\
\mathrm{c}_{8} & =2\left(\mathrm{v}_{1}^{1}-\mathrm{v}_{2}^{1}\right)\left(\mathrm{v}_{1}^{3}-\mathrm{v}_{2}^{3}\right)+2\left(\mathrm{v}_{2}^{1}-\mathrm{v}_{3}^{1}\right)\left(\mathrm{v}_{2}^{3}-\mathrm{v}_{3}^{3}\right) \\
& +2\left(\mathrm{v}_{3}^{1}-\mathrm{v}_{1}^{1}\right)\left(\mathrm{v}_{3}^{3}-\mathrm{v}_{1}^{3}\right) \\
\mathrm{c}_{9} & =2\left(\mathrm{v}_{1}^{2}-\mathrm{v}_{2}^{2}\right)\left(\mathrm{v}_{1}^{3}-\mathrm{v}_{2}^{3}\right)+2\left(\mathrm{v}_{2}^{2}-\mathrm{v}_{3}^{2}\right)\left(\mathrm{v}_{2}^{3}-\mathrm{v}_{3}^{3}\right) \\
& +2\left(\mathrm{v}_{3}^{2}-\mathrm{v}_{1}^{2}\right)\left(\mathrm{v}_{3}^{3}-\mathrm{v}_{1}^{3}\right)
\end{aligned}
$$

確率变数 $\alpha_{1}, \alpha_{2}, \alpha_{3}$ は独立で期待值は 0 、相関はなく、 標準偏差 $\sigma$ の正規分布に従うと考えると目的関数 $\mathrm{f}$ の 期待値 $\mathrm{E}[\mathrm{f}]$ は

$$
E[f]=c_{0}+\left(c_{4}+c_{5}+c_{6}\right) \sigma^{2}
$$

また、目的関数 $\mathrm{f}$ の分散 $\operatorname{Var}[\mathrm{f}]$ は次式で与えられる。

$$
\begin{aligned}
\operatorname{Var}[f] & =E\left[(f-E[f])^{2}\right] \\
& =E\left[f^{2}\right]-(E[f])^{2} \\
& =\left(c_{1}^{2}+c_{2}^{2}+c_{3}^{2}\right) \sigma^{2} \\
& +\left(2 c_{4}^{2}+2 c_{5}^{2}+2 c_{6}^{2}+c_{7}^{2}+c_{8}^{2}+c_{9}^{2}\right) \sigma^{4}
\end{aligned}
$$

本論では $g=V a r[f]$ をロバスト性の指標とし、 $v_{i}^{0} に$

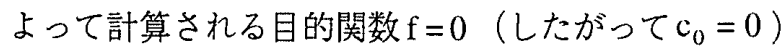
で、かつ $\operatorname{Var}[\mathrm{f}]$ を最小とする構造形態を求めることを 考える。前述のホモロガス構造 (1)(2)(3) の分散 $\operatorname{Var}[\mathrm{f}]$ は各々 $0.36 \times 10^{-2}, 0.36 \times 10^{-2}, 0.23 \times 10^{-2}$ であり、これ 
をロバスト性の指標とすれば分散の最も小さい構造 （3）（Fig. 10）がロバスト性の高いホモロガス構造であ るといえる。このような問題に GA を適用する場合、 次のような目的関数のスカラー化を行い、

$$
\mathrm{h}=\mathrm{f}+\lambda \mathrm{g}
$$

関数 $\mathrm{h}$ を最小化する問題に置き換える場合が多い。し かし、得られる解の精度は、任意の定数 $\lambda に$ 依存し、 満足する解が得られない場合がある。本論では、スカ ラー化関数 $\mathrm{h}$ を最小化するのではなく、繁殖において 1 世代中の個体数の半分を目的関数 $\mathrm{f}$ によって選択 し、残りの半分を目的関数 $\mathrm{g}$ によって選択する一種の 多目的 $\mathrm{GA}^{[\mathrm{s}]}$ の手法を導入する。こうして選択された集 団は交叉によって前述の二つの条件を満足する方向に 解空間を探索することが期待できる。一般に多目的最 適化では二つ以上の目的関数間にトレードオフの関係 が存在し、集合による探索という特徴をもつGAで は、このトレードオフの関係をうまくバランスさせる ことが可能である。本論では適応度を次の二つの式に よって計算した。ただし、渮重Pは部材断面積 Aとヤ ング率 $\mathrm{E} て ゙$ 無次元化し $\mathrm{P} / \mathrm{EA}=1$ とした。また、標準偏 差を $\sigma=0.1$ とした。

$$
\text { fitness }(f)=1 /(1+f), \text { fitness }(g)=1 / g
$$

\section{5 ロバスト性を考慮した解析結果}

Fig. 2 に示した解析モデルに対してロバスト性を考 慮し、多目的GAの手法を導入してホモロガス構造を 解析した結果、Fig. 10に示したホモロガス構造 (3)を

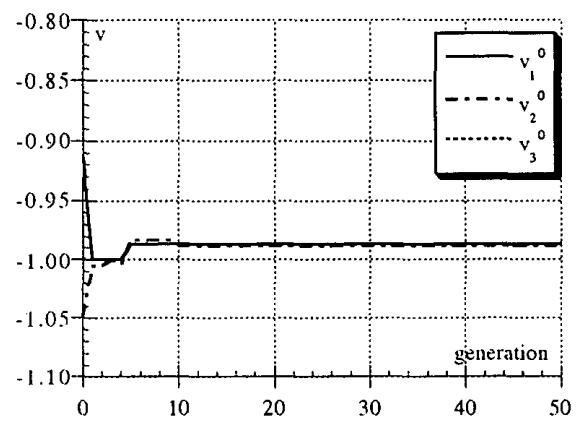

Fig. 11 変位モードの变化

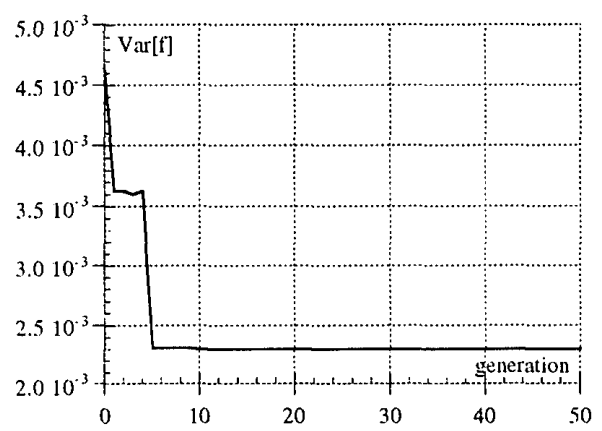

Fig. 12 分散 $\operatorname{Var}[f]$ の変化

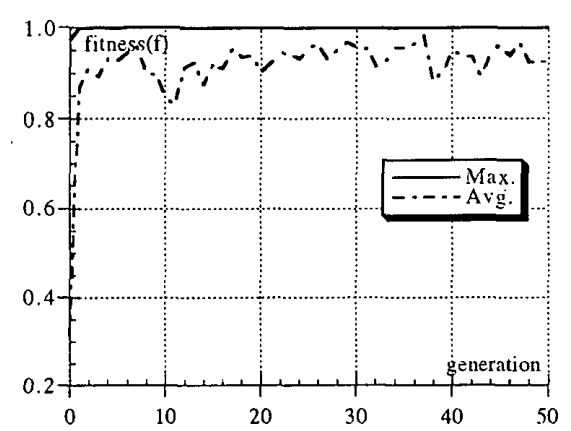

Fig. 13 適応度 fitness(f) の変化

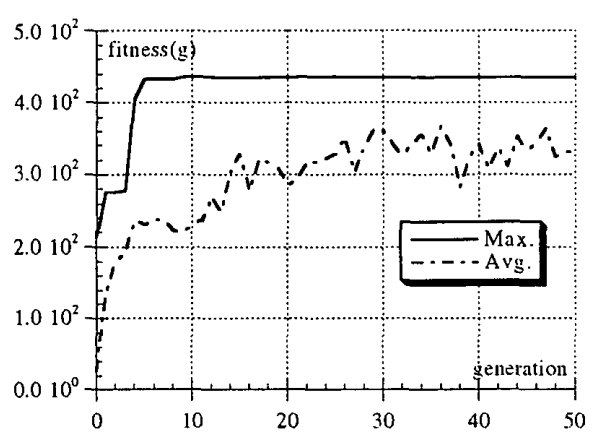

Fig. 14 適応度 fitness $(g)$ の変化

得た。Figs.11,12 は、それぞれ形態形成過程における 変位モードおよび分散 $\operatorname{Var}[\mathrm{f}]$ の変化を示している。ま た、Figs.13,14 は、それぞれ fitness(f), fitness(g)の最 大值（実線）と平均值（破線）の変化を示している。

\section{6 位置と位相と部材断面の最適設計}

Fig. 15 に示すトラス構造を考える。荷重は上弦節 点に鉛直方向に均一に作用するものとし、各部材の弾 性定数は一定とする。また、各部材の断面積 $a_{i}$ は基準 となる断面積を $\mathrm{a}$ として $\mathrm{a} / 4, \mathrm{a} / 2,3 \mathrm{a} / 4, \mathrm{a}, 5 \mathrm{a} / 4,3 \mathrm{a} / 2,7 \mathrm{a} / 4$ の何れ加とする。これらの上弦節点の鉛直方向变位が 同一となるような下弦節点の位置と部材の配置および 部材断面積を GA を用いて解析した。節点位置は各 8 ビット、部材断面積は各 3 ビットで計49ビットの遺伝 子とした。目的関数 $\mathrm{f}$ は対称性を考慮して式（1）で 示される関数とした。

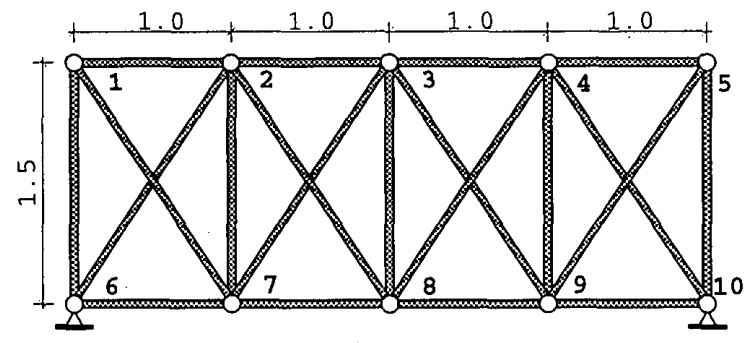

Fig. 15 解析モデル

ただし、荷重Pは基準となる部材断面積aとヤング率 $\mathrm{E}$ で無次元化しP/Ea=1とした。また、GAのパラメータ は個体数 50 、交叉率 0.4 、突然変異率 0.005 とした。 


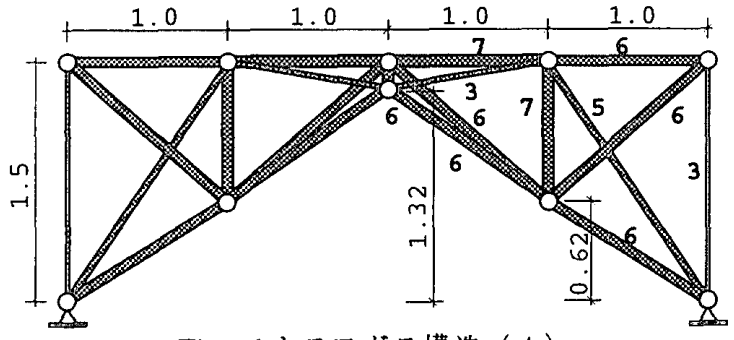

IFig. 16 ホモロガス構造（4）

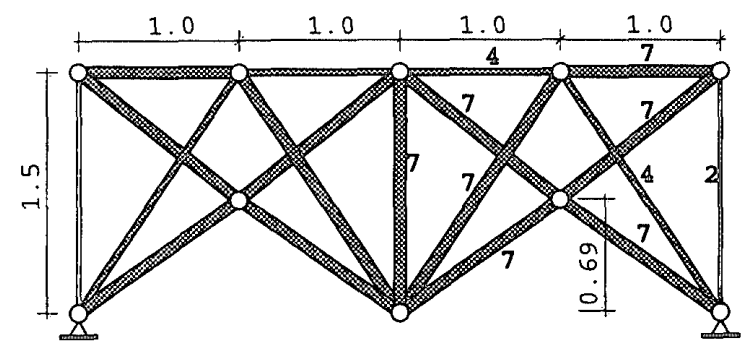

Fig. 17 ホモガス構造（5）

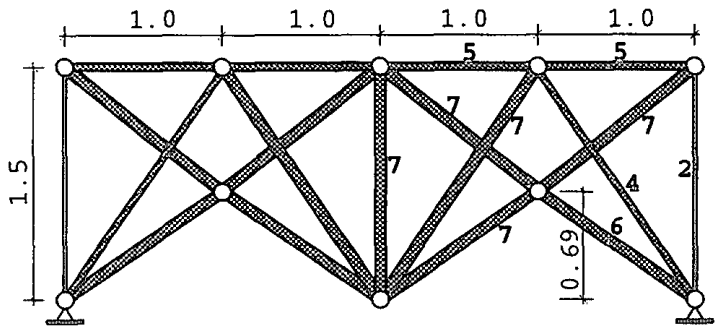

Fig.18ホモロガス構造（6）

Fig. 16は、式（1）の目的関数 $\mathrm{f}$ のみを考慮したホ モロガス条件を満足する形態である。Fig. 17 は式

(9) で $\lambda=500$ とし、目的関数 $\mathrm{f}$ と g をスカラー化 した場合の形態である。Fig. 18 は多目的 GAの手法を 導入した場合の形態である。何れも部材断面は 1 から 7 の数字 $(1: \mathrm{a} / 4,2: \mathrm{a} / 2,3: 3 \mathrm{a} / 4,4: \mathrm{a}, 5: 5 \mathrm{a} / 4,6: 3 \mathrm{a} / 2,7: 7 \mathrm{a} / 4)$

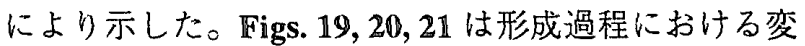
位モードの変化を示したものであり、それぞれFigs. $16,17,18$ に対応する。式（9）の入の設定は難しく、 この值によっては満足な精度の解を得ることができな い場合があり、例えば入=500ではFig. 20に示される ようにスカラー化目的関数による解がホモロガス条件 を十分に満足していないことがわかる。Figs. 22,23は

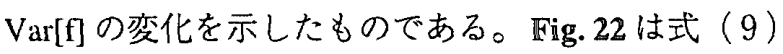
による場合であり、300 世代で $\operatorname{Var}[\mathrm{f}]=0.775 \times 10^{-2}$ が 得られた。更ig. 23 は多目的 GAの手法を導入した場合 であり、300 世代で $\operatorname{Var}[\mathrm{f}]=0.849 \times 10^{-2}$ が得られた。 多目的GAの手法を導入して得られたFig. 18 に示され る形態は、Fig. 16 に示さ机る形態の $\operatorname{Var}[\mathrm{f}]=0.555 \times$ $10^{-1}$ に比較して十分小さい值であり、ホモロガス条件 を満足することも Fig. 21により明らかである。Fig. 2 のような簡単なシステムではホモロガス変形を満足す

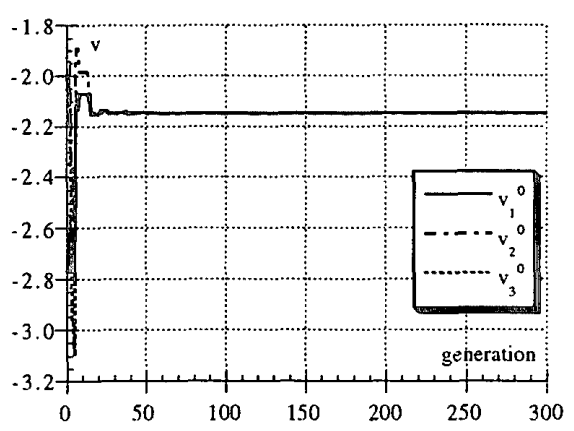

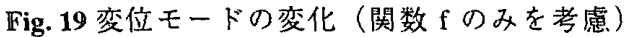

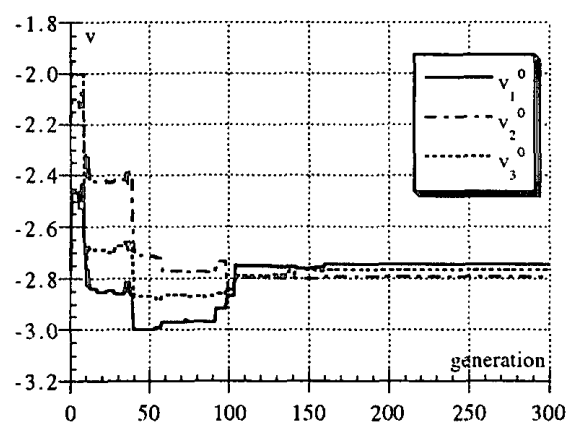

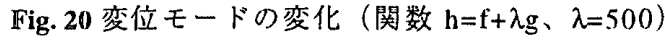

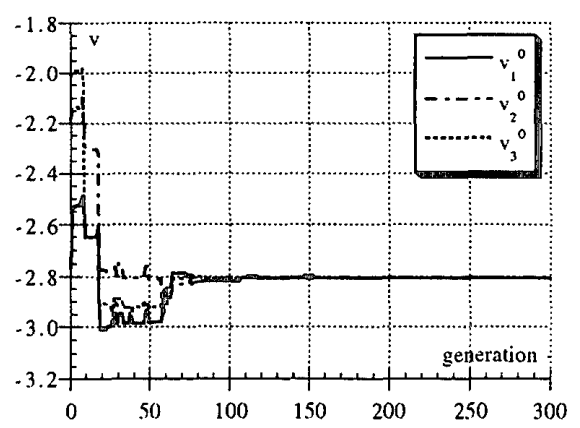

Fig. 21 変位モードの変化（多目的GA）

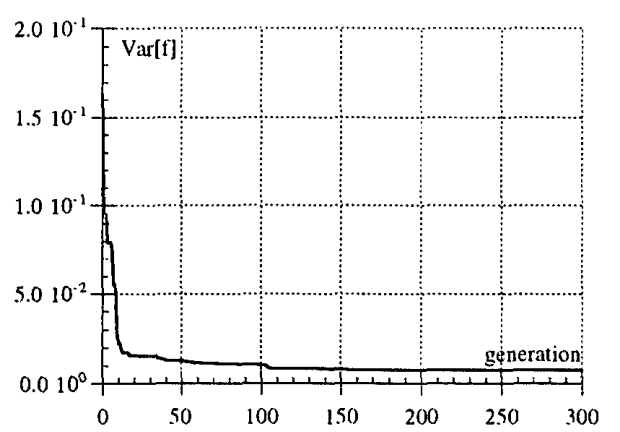

[Fig. 22 分散 Var[f] の変化（関数 $h=f+\lambda g 、 \lambda=500 ）$

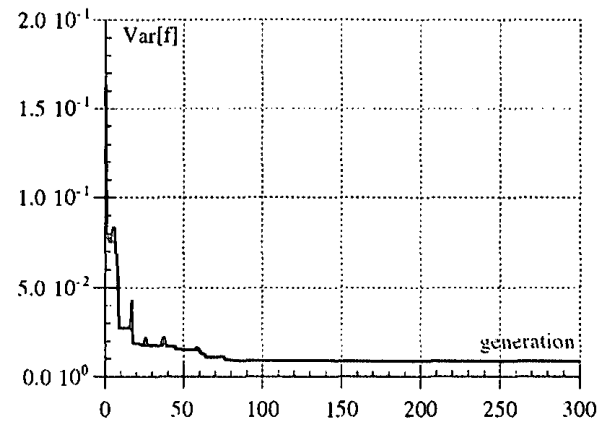

Fig. 23 分散 Var[f] O)变化（多目的GA） 
る全ての形態を数回の試行で見つけ、それらの形態に 対するVar[f] を計算すれば、ロバスト性の高いホモロ ガス構造を見つけることも可能かも知れない。しか し、複雑なシステムでそれを期待することは難しく、 多目的GAの有効性が期待できる点である。

\section{4. 曲面形態生成への応用}

連続型の構造システムの形状決定問題への遺伝的ア ルゴリズムの適用の可能性を示すために最も単純な例 題として極小曲面問題をとりあげる。

Figs. 27, 30 に示すような与えられたフレームに張ら れる極小曲面を求める問題を解析する。Fig. 24 に示す

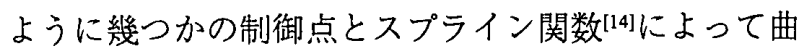
面を表現し、この制御点の位置を遺伝子としてコー ディングすることによって GA を導入する。

3 次元空間内に与えられた制御点をパラメトリック スプラインによって補間して曲面を表現する。パラ メータとして $\phi$ 抢よび $\theta$ を導入し、空間座標 $\mathrm{x}, \mathrm{y}, \mathrm{z}$ は それぞれ $\phi$ およ゙ $\theta$ の関数であるとする。

$$
\mathrm{x}=\mathrm{x}(\phi, \theta), \mathrm{y}=\mathrm{y}(\phi, \theta), \mathrm{z}=\mathrm{z}(\phi, \theta)
$$

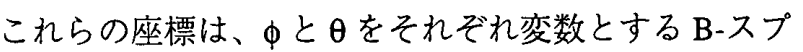
ラインの積によって

$$
\begin{aligned}
& \mathrm{x}(\phi, \theta)=\sum_{\mathrm{i}=1}^{\mathrm{M}} \sum_{\mathrm{j}=1}^{\mathrm{N}} \alpha_{\mathrm{ij}} \mathrm{B}_{\mathrm{i}, \mathrm{k}}(\phi) \mathrm{B}_{\mathrm{j}, \mathrm{l}}(\theta) \\
& \mathrm{y}(\phi, \theta)=\sum_{\mathrm{i}=1}^{\mathrm{M}} \sum_{\mathrm{j}=1}^{\mathrm{N}} \beta_{\mathrm{ij}} \mathrm{B}_{\mathrm{i}, \mathrm{k}}(\phi) \mathrm{B}_{\mathrm{j}, \mathrm{l}}(\theta) \\
& \mathrm{z}(\phi, \theta)=\sum_{\mathrm{i}=1}^{\mathrm{M}} \sum_{\mathrm{j}=1}^{\mathrm{N}} \gamma_{\mathrm{ij}} \mathrm{B}_{\mathrm{i}, \mathrm{k}}(\phi) \mathrm{B}_{\mathrm{j}, \mathrm{l}}(\theta)
\end{aligned}
$$

と表わすことができる。ここで $\mathrm{B}_{\mathrm{i}, \mathrm{k}}(\phi), \mathrm{B}_{\mathrm{j}, 1}(\theta)$ はそれぞ れ $(\mathrm{k}-1)$ 次、(1-1) 次のB-スプラインであり、 $\alpha_{\mathrm{ij}}, \beta_{\mathrm{ij}}, \gamma_{\mathrm{ij}}$ は、制御点を含む全てのデータ点の座標値を用いて構

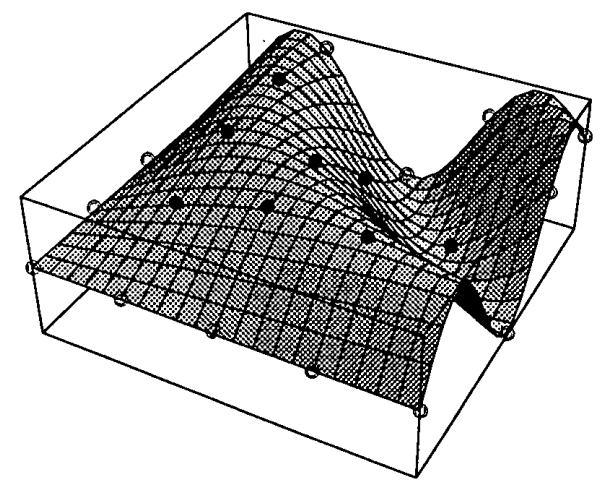

Fig. 24 スプライン曲面と制御点
成される連立方程式を解くことによって決定される定 数である。また、M, N は、それぞれ1本の $\phi$ 曲線, $\theta$ 曲線上のデータ点の個数である。

本論では、曲面上に等間隔に選択した 25 のデータ 点のうちフレーム上の 16 点(๑)を除く 9 個の点(・)を 制御点とした。また、 $\mathrm{k}=1=4$ として 3 次のB-スプラ インを用いた。デー夕点の $\mathrm{x}, \mathrm{y}$ 座標は一定とし、 $\mathrm{z}$ 座 標のみを変化することによって形状を制御する。各制 御点の $\mathrm{z}$ 座標は、それぞれ 8 ビットの 2 進数で表現 し、これを連結した計 72 ビットを遺伝子とした。こ のようにしてフレームに張られた曲面の面積を s と し、目的関数 $\mathrm{s}$ を最小とする曲面を探索する。適応度 は、各個体の面積を $s_{\mathrm{i}}$ として次式により計算した。

$$
\text { fitness }=f_{\text {min }}+\mu\left(f_{i}-f_{\text {nin }}\right)
$$

ここで、 $\mu$ は任意の定数であり、 $\mathrm{f}_{\mathrm{i}}$ は各個体の面積の 逆数 $\mathrm{f}_{\mathrm{i}}=1 / \mathrm{s}_{\mathrm{i}}$ であり、 $\mathrm{f}_{\text {nun }}$ はそれら各個体の適応度 $\mathrm{f}_{\mathrm{i}}$ の 中の最小の適応度である。これは、進化の後期におい て各個体の面積に差が少なくなり、淘汰による効果が 薄れることを相対評価を導入して補正するためであ る。

\section{1 極小曲面の解析結果}

解析例としてまずFig. 27 に太線で示すフレームに 張る極小曲面を考える。GAのパラメータは離散型の システムの解析に用いたのと同様に、個体数は 50、交

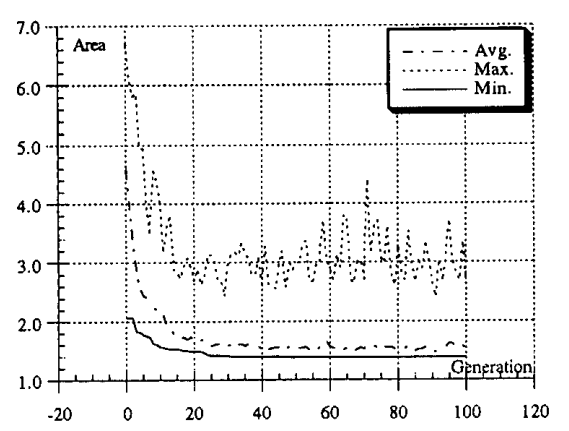

Fig. 25 表面積の変化（フレームA）

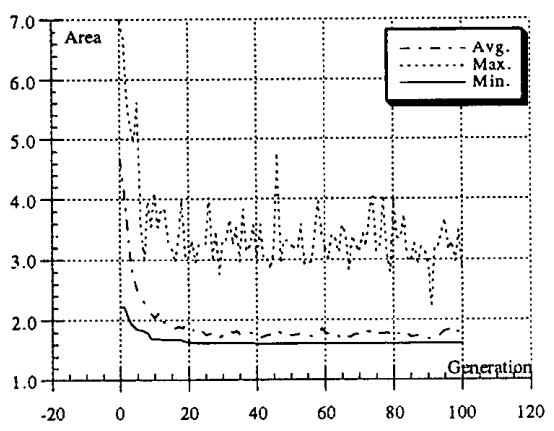

Fig. 26 表面積の変化（フレームB） 


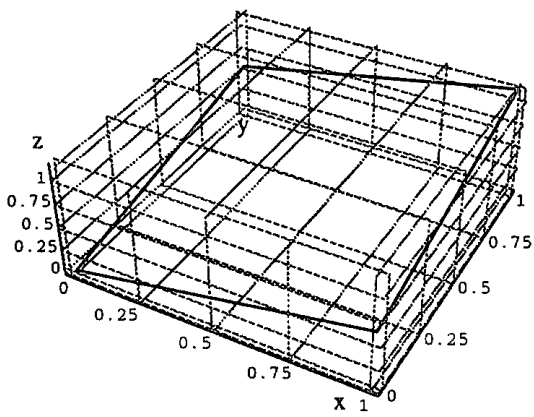

Fig. 27 フレーム A

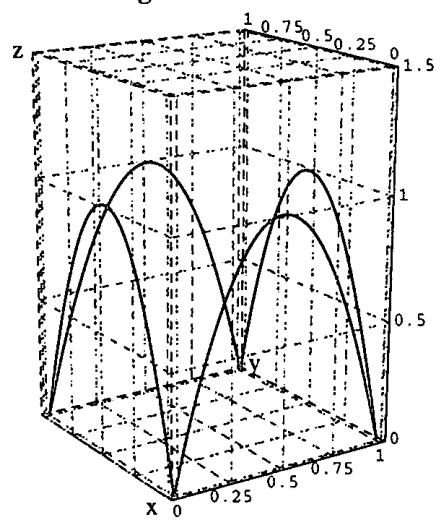

Fig. 30 フレーム B

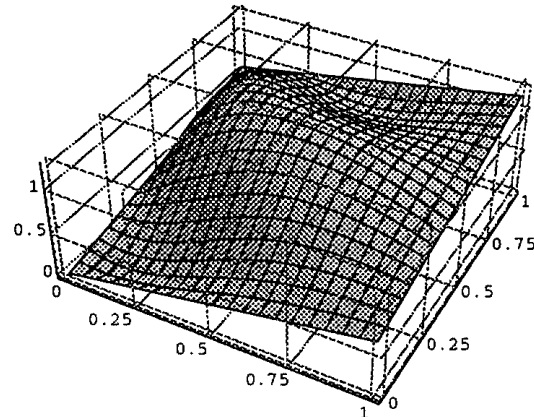

Fig. 28 初期世代

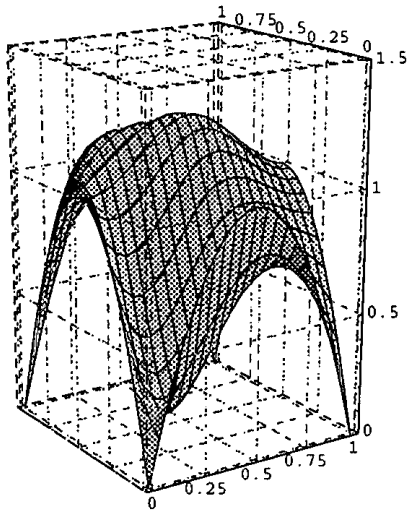

Fig. 31 初期世代

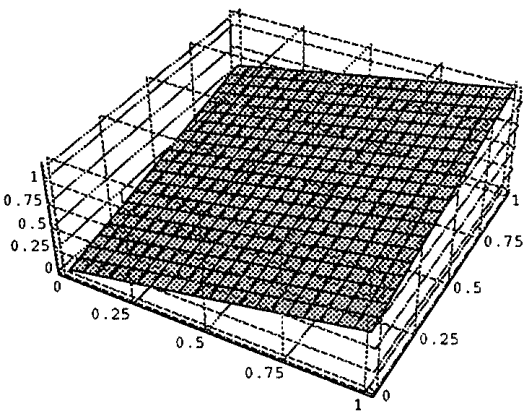

Fig. 291000 世代

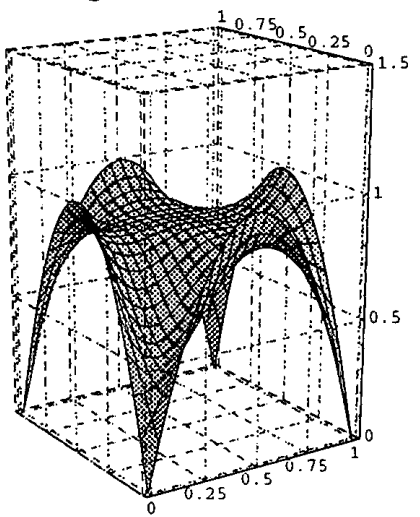

Fig. 32100 世代
叉は各制御点毎に交叉点を設けた多点交叉とし交叉率 は 0.4 、突然変異率は 0.005 とした。Fig.28 はこのフ レームに張られる曲面として初期世代においてランダ ムに与えられた 50 の曲面のうち、最も面積の小さい 曲面である。初期世代には、この約 3 倍程度の面積を もった曲面まで様々な曲面が存在する。Fig. 25 は形態 形成過程における面積の変化を 100 世代にわたって示 したものである。一点鎖線は 50 個体の平均值、点線 は各世代の最大值、また実線は各世代の最小值を示し ている。遺伝的アルゴリズムにより集団全体が極小曲 面となるように進化の過程を繰り返すことがわかる。

Fig. 29は100世代目に得られた曲面形態である。この とき面積は $s=1.34$ となった。Fig. 27 のフレームに張 られる極小曲面 (正解) は、 $\mathrm{z}=\mathrm{x} / \sqrt{3}+\mathrm{y} / \sqrt{3}$ で表わさ れる面積 4/3の平面である。Fig. 29 の曲面形態扔よび その面積を比較すると、遺伝的アルゴリズムによって 精度の良い近似解が得られたことがわかる。

もう一つの解析例として Fig. 30に示されるフレー ムに張られる極小曲面を考える。Fig. 31 はこのフレー ムに張られる曲面として初期世代における最も面積の 小さい曲面である。Fig. 26に示されるような形態形成 過程を経た結果、100世代目に Fig. 32 に示される曲 面形態が得られた。Fig. 33 に要素数 258、節点数 180 の有限要素法による近似解 ${ }^{[11,12]}$ との比較を示す。図中 には得られた曲面を $\mathrm{y}=0.25$ の平面と $\mathrm{y}=0.5$ の平面

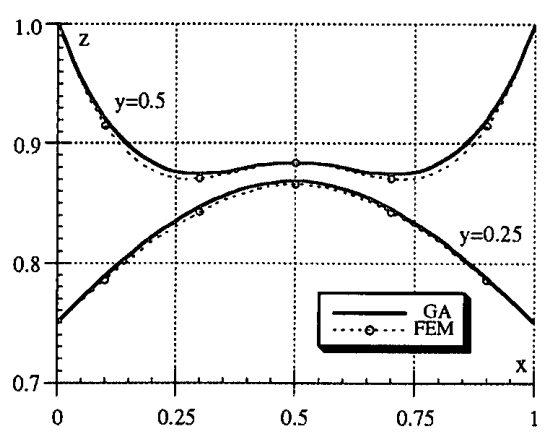

Fig. 33 有限要素解との比較

で切断したときの切り口の曲線が GA による実線と有 限要素法（FEM）による点線で示されている。有限要 素法による解と GAによる解の差は最大で $0.8 \%$ 程度 である。尚、有限要素法による解析では NewtonRaphson 法が用いられ、初期值の選択が解の収束に敏 感に影響するため、初期值の選定には何らかの工夫が 必要である。

\section{5.まとめ}

離散型の構造システムであるトラス構造物のホモロ ガス変形を指定した構造設計問題をとりあげ、これに 遺伝的アルゴリズムを適用した。ここではまず考慮さ れる位相パターンが 4 種類で形態変化を受ける節点数 が 1 の単純な場合について GA を応用する方法につい 
て述べ、その特徵と期待できる点のいくつかを示し た。また、複数の解の中から一つを選び出すための基 準としてロバスト性をとりあげ、多目的 GA の手法を 導入した。さらに、これらの方法を位相の決定に関連 する部材数や、位置を決定しなければならない節点数 さらに部材断面積など、設計パラメータが増加した場 合に適用してその有効性を示すことができた。また、 極小曲面問題をとりあげ連続型の構造システムの形態 解析に $\mathrm{GA}$ を適用する手掛かりについて述べた。GA は非常に単純なアルゴリズムであるが、さまざまな創 意工夫[17] が可能である。今後の発展と応用が期待でき る。

\section{参考文献}

1) 半谷裕彦: 構造物の形態解析と創生, 生研セミナー テキスト,pp.1-21, 1994

2) 半谷裕彦,関富玲: ホモロガス変形を制約条件とす る立体トラス構造の形態解析, 日本建築学会構造 系論文報告集, 第405号, pp.97-102, 1989

3) 半谷裕彦, 原田和明: 変位モード指定の構造形態解 析法, 日本建築学会構造系論文報告集, 第453号, pp. $95-100,1993$

4) D. E. Goldberg: Genetic Algorithms in Search, Optimization, and Machine Learning, Addison-Wesley, 1989

5) J. Horn, N. Nafpliotis, D. E. Goldberg: A Niched Pareto Genetic Algorithm for Multiobjective Optimization, Proc. 1st ICEC, 82-87, 1994

6) Ramm, E.: Shape finding methods of shells, Bulltin of the International Association for Shell and Spatial Structures (IASS), Vol. 33, pp. 89-98, 1992

7) 大森博司, 大木洋司, 中増裕介: 吊り下げ曲面の形 状解析, 日本建築学会構造系論文集, 第468号, 109-118, 1995

8) 大森博司, 萩原伸幸, 松井徹栽, 松岡理: 有限要素法 による極小曲面の数值解析, 膜構造研究論文集, pp.1-10, 1988

9) 登坂宣好, 福島則博: 一般化された境界要素法に よる極小曲面問題の近似解法, 境界要素法論文集, 第6巻, pp.49-54, 1989

10)鈴木俊男, 半谷裕彦: 極小曲面の変数低減による有 限要素解析, 日本建築学会構造系論文報告集, 第425号, pp.111-120,1991

11)鳥羽安量、三井和男, 登坂宣好: 対話型可視化シ ステムによる空間構造の形状決定, 日本建築学会 関東支部研究報告集, pp.93-96, 1994

12)鳥羽安量、三井和男, 登坂宣好: 対話型支援可視 化システムによる空間構造の形状決定, 日本建築 学会大会学術講演梗概集, pp.2045-2046, 1994
13)Holland,J.: Adaptation in Natural and Artificial Systems, Ann Arbor: The University of Michigan Press, 1975

14) G. Farin : Curves and Surfaces for Computer Aided Geometric Design A Practical Guide, Academic Press, 1990

15)三井和男, 富田啓一, 登坂宣好: 構造形態解析にお ける遺伝的アルゴリズムの応用, 日本建築学会大 会学術講演梗概集, pp.1211-1212, 1994

16)三井和男, 登坂宣好：遺伝的アルゴリズムによる 曲面形態の生成, 日本建築学会大会学術講演梗概 集,pp.477-478, 1995

17)富田啓一, 登坂宣好：可变突然変異率を有する遺 伝的アルゴリズムによる最適設計問題，日本機械 学会論文集, 61巻585号, pp.228-233, 1995

（1995年 7 月10日原稿受理，1996年 1 月 17 日採用決定） 